\title{
Productive aspects of pigs fed forage cactus silage associated with feed restriction
}

\author{
G.M. Araújo ${ }^{1 \#}$, T.D.D. Martins ${ }^{2}$, P.E.N. Givisiez ${ }^{1}$, L.A.F. Pascoal ${ }^{2}$, R.S. Oliveira ${ }^{2}$, A.C. Oliveira $^{3}$, \\ J.H.V. Silva ${ }^{2}$ \& R.R. Guerra ${ }^{1}$ \\ ${ }^{1}$ Centro de Ciências Agrárias, Universidade Federal da Paraíba, Rodovia PB079, 58397-000, Areia, Brazil \\ ${ }^{2}$ Centro de Ciências Humanas, Sociais e Agrárias, Universidade Federal da Paraíba, Zona Rural 58222-000, \\ Bananeiras, Brazil \\ ${ }^{3}$ Universidade Estadual do Oeste do Paraná, Rua Pernambuco 85960-000, Marechal Cândido Rondon, Brazil
}

(Received 14 September 2016; Accepted 5 June 2018; First published online 15 August 2018)

Copyright resides with the authors in terms of the Creative Commons Attribution 4.0 South African Licence.
See: http://creativecommons.org/licenses/by/4.0/za
Condition of use: The user may copy, distribute, transmit and adapt the work, but must recognise the authors and the South African
Journal of Animal Science.

\begin{abstract}
This study aimed to evaluate the use of silage of forage cactus (Opuntia ficus-indica Mill) in diets for finishing pigs. Two experiments were conducted: the first for digestibility and the second for performance. In the performance trial, the quantitative levels of feed restriction $(0 \%, 10 \%, 20 \%$, and $30 \%)$ were evaluated, which were associated with the supply of forage cactus silage. Forage cactus silage presented 2463.59 and $2456 \mathrm{kcal} / \mathrm{kg}$ of digestible and metabolizable energy, respectively. The feed restriction levels associated with the supply of forage cactus silage influenced feed intake, weight gain and final weight negatively, but did not affect feed conversion. Carcass absolute weight was influenced negatively. However, the yield of carcass and cuts and the amount of meat in the carcass were not influenced. With the increase in feed restriction, there was a decrease in duodenal mucosa thickness, intestinal glands, liver glycogen storage and the occurrence of inflammation in the submucosa and intestinal mucosa. Forage cactus silage is not accepted well by animals. The restriction up to $30 \%$ of balanced feed did not affect feed conversion, yield of carcass and cuts and economic viability. However, levels over $10 \%$ affected intestinal health.
\end{abstract}

Keywords: Alternative feed, feed preservation, intestinal health, Opuntia ficus-indica Mill, pig nutrition

\#Corresponding author: gilson.mendes@ifpi.edu.br

\section{Introduction}

Forage cactus (Opuntia ficus-indica Mill) is a plant that is well adapted to semi-arid regions and has multiple uses, serving as a food source for humans and animals. Owing to its nutritional composition and the variety of products and by-products that can be extracted from it, this cactus species has significant social and economic importance for these regions (FAO, 2013).

This species has high palatability and digestibility for several species of animals, especially for ruminants. In nutritional aspects, forage cactus has a low content of dry matter (DM) (10-15\%), high content of total carbohydrates (55-77\%), organic matter (OM) and total digestible nutrients (65-70\%). In this sense, owing to its composition and the ease of obtaining the cactus in the northeast region of Brazil, it is important to evaluate the use of forage cactus for non-ruminant animal production.

Ensiling is a preservation method that consists of storing feed under anaerobic conditions, resulting in a fermentation process. In this process, various energy substrates, including soluble sugars, organic acids, and soluble nitrogen compounds, are used by fermentative bacteria to produce volatile fatty acids such as lactate, acetate, propionate and butyrate (Santos et al., 2010). The ensiled product retains a much higher proportion of nutrients than the dry collected product stored as hay (McDonald et al., 1991).

Feed restriction is a practice that may be used to reduce production costs, improve feed efficiency, and reduce the deposition of fat in the carcasses, thereby increasing the proportion of meat to fat ratio. The restriction could be qualitative or quantitative. The first restriction was performed by including low digestibility feed in the diet. The second one was performed by restricting the amount of feed offered daily to the animals. However, the efficiency of feed restriction programmes depends on the age of the animals at the 
beginning of the restriction and restriction level and time, given that if the restriction is established in a rigorous manner, it may affect the animal's health and production (Pugliese et al., 2013).

The quantitative reduction of balanced feed and the simultaneous supply of an alternative feed that has high nutritional levels and low cost, such as forage cactus silage, may reduce feed costs without affecting the performance variables.

Since there are no publications on the use of forage cactus silage for non-ruminant animals, this study aimed to evaluate the composition of silage of forage cactus (Opuntia ficus-indica Mill) of the giant variety and test it for finishing pigs, associated with restriction of balanced feed, evaluating performance characteristics, carcass quantitative characteristics, the development of the digestive system organs, liver glycogen levels, blood biochemical parameters, duodenum morphometric analysis and economic viability.

\section{Materials and Methods}

The experiments were performed at the Centre for Social, Human and Agricultural Sciences (CCHSA/UFPB), in the municipality of Bananeiras, Paraíba State, Brazil. Two experiments were conducted: a digestibility study and performance evaluation. The entire experiment was performed according to the norms and approval of the Ethics Committee on the Use of Animals of the Federal University of Paraíba, certificate number 069/2016.

Forage cactus was acquired from farmers who did not use agronomic practices to cultivate it. The authors chose the species Opuntia ficus-indica Mill (giant variety) because of its higher availability in the region. All the cladodes were collected in the field, sliced into 2-3 cm pieces, and exposed to air for five days, aiming at dehydration and loss of $60 \%$ of the initial weight. Then the material was ensiled in silos of $50 \mathrm{~L}$ and $180 \mathrm{~L}$, which were compressed and sealed. The material remained ensiled for 60-150 days. To liberate excess gas, the tops of the containers were fitted with registers.

Bromatological analysis was performed to determine the levels of $\mathrm{Ca}^{++}, \mathrm{Na}^{+}, \mathrm{K}^{+}$, crude protein (CP), ether extract (EE), gross energy (GE), crude fibre (CF), OM, mineral matter (MM), non-fibrous carbohydrates (NFC), carbohydrates (CHO) (Silva \& Queiroz, 2002), neutral detergent fibre (NDF) and acid detergent fibre (ADF) contents (Van Soest et al., 1991).

Silage samples were taken from the middle portion of the silos, at days 60,120 and 150 of fermentation, and packaged and frozen for later determination of the concentrations of short-chain fatty acids, namely lactic, acetic, propionic and butyric acid (Sheperd et al., 1995). After processing the samples, the acid concentrations were determined by high performance liquid chromatography (HPLC) (Shimadzu, model SPD-10A VP), coupled to an ultra violet detector, using a wavelength of $210 \mathrm{~nm}$.

Twelve castrated male pigs (Agroceres ${ }^{\circledR}$ lineage) were used, with average initial weight of $66.0 \pm 5.0$ $\mathrm{kg}$ (live weight), distributed in a randomized block design, according to the weight range, with two treatments and six replications, adopting each animal as an experimental unit. The treatments consisted of a basal diet and another diet in which the forage cactus silage replaced $30 \%$ of the reference diet.

The trial lasted 15 days, the first ten days for the animals' adaptation to the cages and experimental diets, and the five last days to collect faeces and urine. The authors adopted the total collection method described by Sibbald \& Slinger (1963). During the trial period, they recorded maximum and minimum average temperatures of $26.0 \pm 3^{\circ} \mathrm{C}$ and $22.8 \pm 2{ }^{\circ} \mathrm{C}$, respectively, and air relative humidity of $72 \pm 10 \%$.

The calculation of the amount of feed provided to each animal during the five days of collection was set according to the lowest consumption per metabolic weight $\left(\mathrm{kg}^{0.75}\right)$ recorded during the adaptation period for each experimental unit (Sakomura \& Rostagno, 2007). During the trial period, the method described by Sakomura and Rostagno (2007) for feed supply and faeces and urine collection was used. After laboratory analysis the coefficients of digestibility of DM, OM, MM, CP, EE, NDF and ADF were calculated according to this formula: nutrient digestibility (\%) $=$ [(ingested nutrient - excreted nutrient)/ingested nutrient $] \times 100$ and GE, as well as digestible energy (DE) and metabolizable apparent energy corrected for nitrogen (AMEn), and their digestible nutrients, using the equations of Matterson et al. (1965).

Twenty castrated male pigs (Agroceres ${ }^{\circledR}$ lineage) were used, with an average weight of $64 \pm 8 \mathrm{~kg}$. The treatments consisted of a basal diet and three quantitative restriction levels (0\%,10\%,20\%, and $30 \%)$ in addition to the ad libitum supply of forage cactus silage to the animals that received the restriction levels. The animals of the control group (0\%) did not receive silage. Each animal represented an experimental unit, and five replications were performed, totalling 20 experimental units.

The experimental diets, based on corn, soybean meal and supplementation with mineral, vitamins, and synthetic amino acids, were formulated to meet the nutritional requirements of high genetic potential pigs, according to the recommendations of Rostagno et al. (2011) (Table 1).

The supply of balanced feed was conducted in the morning and afternoon, and feed and silage were provided in separate feeders. The calculation of the amount of balanced feed provided daily to the restricted animals was based on the individual consumption of the animals from the control group in each block. Water 
was provided to all animals ad libitum. During the trial period, maximum and minimum average temperatures of $31 \pm 3^{\circ} \mathrm{C}$ and $22 \pm 1{ }^{\circ} \mathrm{C}$, respectively, were recorded, and maximum and minimum air relative humidity of $93 \pm 2$ and $44 \pm 4 \%$, respectively.

Table 1 Feed composition and nutritional levels of pig diets according to the recommendations of Rostagno et al. (2011)

\begin{tabular}{lclc}
\hline Ingredients & Percentage of ration & Calculated composition & Amount \\
\hline Corn & 81.80 & Energy met. (Mcal/kg) & 3.23 \\
Soybean meal & 14.08 & Crude protein (\%) & 13.83 \\
Soybean oil & 0.52 & Calcium (\%) & 0.472 \\
Dicalcium phosphate & 0.74 & Available phosphorus (\%) & 0.23 \\
Limestone & 0.57 & Lysine Dig. (\%) & 0.76 \\
Salt & 0.32 & Arginine (\%) & 0.74 \\
Inert $^{1}$ & 1.00 & Met+ cist. Dig. (\%) & 0.46 \\
BHT $^{2}$ & 0.01 & Methionine Dig.(\%) & 0.24 \\
Premix min. \& vit. $^{3}$ & 0.50 & Threonine Dig. (\%) & 0.51 \\
L-Lysine HCL $^{\text {L-Threonine }}$ & 0.33 & Tryptophan Dig. (\%) & 0.14 \\
DL-Methionine & 0.09 & Valine Dig. (\%) & 0.54 \\
L-Tryptophan & 0.03 & Potassium (\%) & 0.50 \\
- & 0.02 & Sodium (\%) & 0.16 \\
Total & - & Neutral detergent fibre (\%) & 11.32 \\
& 100.00 & DEB (mEq/kg) & 133.13
\end{tabular}

${ }^{1}$ Washed sand

${ }^{2}$ Antioxidant butylated hydroxytoluene (BHT)

${ }^{3}$ Mineral and vitamin premix assurance levels per $\mathrm{kg}$ of product: vitamin A: 532,000 iu, vitamin B: 112,000 iu, vitamin E: $2100 \mathrm{iu}$, vitamin $B_{1}$ (thiamine): $138 \mathrm{mg}$, riboflavin $\left(B_{2}\right): 490 \mathrm{mg}$, pyridoxine $\left(B_{6}\right): 97 \mathrm{mg}$, vitamin $B_{12} 1680 \mathrm{mcg}$, vitamin K: $280 \mathrm{mg}$, niacin: $2800 \mathrm{mg}$, biotin: $10 \mathrm{mg}$, pantothenate: $1680 \mathrm{mg}$, folic acid: $70 \mathrm{mg}$, choline: $15 \mathrm{~g}$, copper: $21 \mathrm{~g}$, cobalt: $100 \mathrm{mg}$, iron: $12 \mathrm{~g}$, manganese: $6200 \mathrm{mg}$, zinc: $24 \mathrm{~g}$, iodine: $200 \mathrm{mg}$, selenium: $42 \mathrm{mg}$, bacitracin zinc: 11,000 m.

${ }^{4}$ DEB: dietary electrolyte balance

Feed intake $(\mathrm{Fl})(\mathrm{kg} /$ day), daily weight gain (DWG) (kg/day), total silage intake (TSI) (kg/trial period), final weight $(F W)(\mathrm{kg})$, and feed conversion $(F C)(\mathrm{kg} / \mathrm{kg})$ were evaluated. When the animals reached an average weight of $110 \mathrm{~kg}$, they were slaughtered in blocks over five days.

At the end of the experiment, two blood samples by animal were collected in vacutainer tubes with heparin. The first collection was conducted in the morning before the fasting of the animals began. The second was performed during the bleeding of the pigs at the slaughterhouse, after fasting for 12 hours. The blood sample was centrifuged at $3500 \mathrm{rpm}$ for 15 minutes at $4{ }^{\circ} \mathrm{C}$ to obtain blood plasma, which was frozen immediately. The plasma components that were ascertained were urea $(\mathrm{mg} / \mathrm{dL})$, total proteins $(\mathrm{g} / \mathrm{dL})$, albumin $(\mathrm{g} / \mathrm{dL})$, creatinine $(\mathrm{mg} / \mathrm{dL})$, triglycerides $(\mathrm{mg} / \mathrm{dL})$, cholesterol $(\mathrm{mg} / \mathrm{dL})$ and glucose $(\mathrm{mg} / \mathrm{dL})$, using Labtest $₫$ kits and a Mindray Chemistry Analyzer machine (Model BS-120).

When the pigs reached average slaughtering weight $(110 \mathrm{~kg})$, they were submitted to a 12-hour fasting period and then all animals were slaughtered at the slaughterhouse of the Centre for Human, Social and Agricultural Sciences. After resting, each animal was stunned with an electric current, bled, depilated and eviscerated.

Heart, kidneys, spleen, liver, pancreas, full and empty stomach, full and empty small intestine, full and empty cecum, and full and empty colon were weighed. After emptying and washing the intestine, its length was measured according to the method of Le Gall et al. (2007).

The carcasses were weighed at the end of slaughter to obtain the hot carcass weight $(\mathrm{HCW})$, and reweighed at 24 hours after cooling in a cold chamber at $2{ }^{\circ} \mathrm{C}$ to obtain the cold carcass weight (CCW). The carcass yield (\%) was calculated dividing the hot carcass weight by the live weight of the animal in fasting, at the end of the experiment, and multiplying the result by 100. Based on the CCW and HCW, carcass weight 
loss in cooling was calculated, adopting the method described by Bridi \& Silva (2007). Carcass length was obtained with a metal measuring tape, according to the Brazilian method of carcass evaluation (ABCS, 1973). To evaluate the backfat thickness, the measurements were taken at the height of the first rib, last rib and last lumbar, using a digital calliper, according to the method described by Bridi \& Silva (2007). To analyse the longissimus dorsi depth, the method described by Bridi \& Silva (2007) was adopted. Meat yield and amount of meat on the carcass were evaluated according to the equations proposed by Guidoni (2000).

After 24 hours of cooling in a cold chamber at $2{ }^{\circ} \mathrm{C}$, the pork leg, shoulder, rib, loin, fillet and belly were weighed. The estimation of the yield of cuts was performed according to Bridi \& Silva (2007). To determine the carcass $\mathrm{pH}$, a portable digital $\mathrm{pH}$ meter was used (HOMIS, model 801). $\mathrm{pH}$ values were determined 45 minutes after slaughter (initial $\mathrm{pH}$ ) and at 24 hours post mortem (final $\mathrm{pH}$ ) in the cold carcasses (Rosa et al., 2001). Caecal content samples were placed in plastic containers to determine the $\mathrm{pH}$, using Tecnal pH meter TEC-2, according to the method of Instituto Adolfo Lutz (1985).

Short-chain fatty acids (acetic, propionic and butyric) were evaluated in the cecum content. A sample of $10 \mathrm{~g}$ was collected, weighed and acidified in $30 \mathrm{~mL}$ formic acid at $16 \%$ to inactivate the fermentation processes. Subsequently, the samples were refrigerated for 72 hours and homogenized twice daily. Then, they were centrifuged at $5000 \mathrm{rpm}$ at $15^{\circ} \mathrm{C}$ for 15 minutes. Afterwards, the supernatant was collected and frozen to determine the concentrations of fatty acids. Identification and quantification of the fatty acids were carried out using HPLC, as performed in the digestibility trial.

The histological processing was performed in the Histology Laboratory of the Postgraduate Programme in Animal Science (UFPB/CCA). Biological samples of intestine and liver were collected and fixed in metacarn solution (60\% methanol, 30\% chloroform, 10\% acetic acid) (Heleno et al., 2011) for 12 hours and embedded in paraffin. The sections were $5 \mu \mathrm{m}$ thick. Haematoxylin-eosin staining and periodic acid-Schiff stain (PAS) were carried out. The scanned images were captured with an Olympus BX-60 microscope with Zeiss AxioCam and Motic Image Plus 2.0 software.

For the morphometric analysis of the intestinal mucosal thickness, five animals from each treatment were used, according to histological processing (above). For each animal, three photomicrographs were scanned with a $5 \times$ lens. Three measurements were performed on each photomicrograph, totalling 45 measurements per treatment $(n=45)$. For the analysis of the storage index of liver glycogen, the PAS was used, which stains glycoproteins such as liver glycogen. The optical microscopy analysis of the photomicrographs, six for each animal, totalling 30 photos per treatment $(n=30)$, was performed by a histologist who was unaware of the group of each pig. The photomicrographs were classified according to the level of glycogen storage based on the positive PAS staining: low liver glycogen storage (level+), moderate liver glycogen storage (level++) and high liver glycogen storage (level+++). To analyse the storage index of liver glycogen the crosses $(+)$ were converted into corresponding numbers $(+=1,++=2,+++=3$ ) to carry out statistical analysis according to the semi-quantitative score (Ishak et al., 1995) (modified).

To evaluate feed economic viability, it was considered the silage production cost and the prices of other raw materials, calculating the diet cost per kilogram of live weight gain, according to the equation proposed by Bellaver et al. (1985). It was also calculated the economic efficiency index (EEI) and the cost index $(\mathrm{Cl})$ (Gomes et al., 1991). To calculate the cost of the experimental diet and the diet containing forage cactus silage, it was considered the prices of the inputs sold in the municipality of Bananeiras (Paraíba State, Brazil).

A randomized block design was used, based on the initial weight of the animals. The performance data and quantitative characteristics of the carcass and organs were submitted to an analysis of variance at $5 \%$ probability, and multiple linear regression up to the third level. For economic viability, Dunnett's test (5\%) was performed to compare the treatment groups with the control group, using the statistical software SAS 9.2. For intestinal morphometric analysis and liver glycogen storage, an ANOVA was performed, followed by Tukey test at 5\% probability, using Graph Pad Prism 5.0 software.

\section{Results and Discussion}

Forage cactus silage has low concentrations of DM, CP, EE and NFC, and high concentrations of $\mathrm{NDF}, \mathrm{CHO}, \mathrm{ADF}, \mathrm{MM}, \mathrm{Ca}^{++}, \mathrm{Na}^{+}$and $\mathrm{K}^{+}$(Table 2). Studies on the evaluation of the nutritional composition of forage cactus silage are scarce in the literature. However, its composition varies according to the variety of cactus, water content of the ensiled material, plant age, order of cladodes, time of the year, type of inoculant and dry matter concentration (Çürek \& Özen, 2004).

The digestibility coefficient of organic matter and gross energy of the silage were high: DE of 2,463.59 $\mathrm{kcal} / \mathrm{kg}$, and AMEn of 2,456.92 (Table 2). In nutritional terms, forage cactus silage showed a satisfactory concentration of metabolizable energy, with around $60 \%$ of the metabolizable energy of humid grain corn silage (3,918 kcal $/ \mathrm{kg})$, which has a higher coefficient of metabolism (82-88\%) (Lohmann et al., 2010). 
Table 2 Total and digestible nutrients, digestibility coefficient and concentration of short-chain fatty acids of forage cactus silage

\begin{tabular}{|c|c|c|c|}
\hline Nutrients & Total & Digestible & Digestibility Coefficient \\
\hline $\mathrm{GE}^{*}(\mathrm{kcal} / \mathrm{kg})$ & $3,613.81$ & $2,463.59$ & 68.17 \\
\hline $\mathrm{AMEn}^{1}(\mathrm{kcal} / \mathrm{kg})$ & $2,456.92$ & - & - \\
\hline Dry matter (\%) & 25.00 & 8.43 & 33.71 \\
\hline Organic matter (\%) & 82.79 & 68.71 & 82.78 \\
\hline Mineral matter (\%) & 17.00 & 5.45 & 32.07 \\
\hline Crude protein (\%) & 6.97 & 4.14 & 59.40 \\
\hline Ether extract (\%) & 1.74 & 0.43 & 24.64 \\
\hline Neutral detergent fibre (\%) & 40.00 & 18.09 & 45.23 \\
\hline Acid detergent fibre (\%) & 19.55 & 7.27 & 37.21 \\
\hline Total carbohydrates (\%) & 74.29 & - & - \\
\hline Non-fibrous carbohydrates (\%) & 34.29 & - & - \\
\hline Calcium (\%) & 3.56 & - & - \\
\hline Potassium (\%) & 2.25 & - & - \\
\hline Sodium (\%) & 0.37 & - & - \\
\hline \multirow{2}{*}{ Short-chain fatty acids (ppm) } & \multicolumn{3}{|c|}{ Days of ensiling } \\
\hline & 60 & 120 & 150 \\
\hline Lactic & $6,692.05$ & $6,669.90$ & $6,827.10$ \\
\hline Acetic & $3,165.42$ & $3,597.10$ & $2,891.27$ \\
\hline Propionic & 480.59 & 601.47 & 178.34 \\
\hline Butyric & 39.28 & 43.32 & 31.59 \\
\hline
\end{tabular}

The average concentration of short-chain fatty acids (lactic, acetic, propionic and butyric acid) in the three periods of ensiling was $2.69 \%, 1.35 \%, 0.19 \%$ and $0.02 \%$, respectively. Çürek \& Özen (2004) found similar results for lactic acid (2.59\%) and acetic acid (1.53\%), but different results for butyric acid (0.34\%). Factors related to the botanical part of the ensiled feed, ensiling method, use of inoculants and ensiling period may influence the production of these acids (Çürek \& Özen, 2004).

The restriction levels of the balanced feed influenced FI $(P<0.01)$, DWG $(P<0.05)$, and TSI $(P<0.01)$. However, FC was not affected $(P>0.05)$ (Table 3). The variable DFI had a standard behaviour according to the method used, decreasing with increasing restriction of the balanced feed. DWG behaviour was similar to FI behaviour, decreasing linearly with the increase of the balanced feed restriction. With every $1 \%$ of feed restriction, WG and DWG decreased by $3.42 \%$ and $0.09 \%$, respectively.

Total silage intake increased linearly with the restriction of the balanced feed. With every $1 \%$ of feed restriction, TSI increased by $4.42 \%$. However, it was insufficient to meet the nutritional requirements of the pigs. The average daily silage intake was only $245 \mathrm{~g}, 220 \mathrm{~g}$ and $461 \mathrm{~g}$ for levels $10 \%, 20 \%$ and 30\% of restriction, respectively. In the performance trial (Table 3 ), unlike the metabolism trial, the animals could choose the feed to be consumed because it was provided separately. Even under restriction conditions, animals preferred the balanced feed. In this sense, the behaviour of such variables is related to the effect of the feed restriction.

The decrease in DWG observed in this study corroborates published studies. Feed restriction reduces the availability of nutrients for production and changes the energy utilization (Daza et al. 2003, Lovatto et al., 2006). During feed restriction, most of the metabolizable energy is used to maintain the animal. At the same time, the highest fraction of retained energy is maintained as protein. These two opposing mechanisms are related to the WG of the animals under restriction (Lovatto et al., 2006). Unlike WG, FC is less sensitive to feed restriction. Moderate restriction $(30 \%)$ has low or no effect on this variable. On the other hand, severe restriction (over 45\%) affects FC negatively (Daza et al., 2003). Thus, the results of this study corroborate 
the data published by Lebret et al. (2001), Daza et al. (2003) and Lovatto et al. (2006), who evaluated restriction levels of $25 \%, 25 \%$ and $40 \%$, respectively, and did not find change in the FC.

Table 3 Effect of feed restriction on feed intake, daily weight gain, feed conversion and total silage intake

\begin{tabular}{|c|c|c|c|c|c|c|c|}
\hline \multirow{2}{*}{ Variables $(\mathrm{Kg})$} & \multicolumn{4}{|c|}{ Inclusion levels of forage cactus silage (\%) } & \multicolumn{2}{|c|}{$P$} & \multirow[b]{2}{*}{$\mathrm{CV}^{3} \%$} \\
\hline & 0 & 10 & 20 & 30 & Lin. $^{1}$ & Qua. $^{2}$ & \\
\hline $\mathrm{FI}$ & 3.15 & 2.83 & 2.52 & 2.21 & 0.001 & 0.560 & 11.77 \\
\hline DWG & 1.34 & 1.17 & 1.15 & 1.05 & 0.002 & 0.550 & 9.96 \\
\hline FC & 2.35 & 2.42 & 2.20 & 2.11 & 0.150 & 0.540 & 11.14 \\
\hline TSI & 0 & 9.07 & 8.16 & 17.08 & 0.001 & 0.380 & 17.34 \\
\hline
\end{tabular}

${ }^{1}$ Lin.: linear effect,

${ }^{2}$ Qua.: quadratic effect,

${ }^{3} \mathrm{CV}$ : coefficient of variation,

FI: feed intake, DWG: daily weight gain, FC: feed conversion, TSI: total silage intake;

Equations: $\mathrm{Fl}: \hat{\mathrm{Y}}=3.147-0.0313 \mathrm{x}, \mathrm{r}^{2}=0.99$, DWG: $\hat{\mathrm{Y}}=1.311-0.0089 \mathrm{x}, \mathrm{r}^{2}=0.91$, TSI: $\hat{\mathrm{Y}}=2.8686000+4.4244 \mathrm{x}, \mathrm{r}^{2}=0.89$

Carcass yield (CY), CutY (leg, rib, shoulder, belly, neck, loin, fillet), carcass length (CL) and backfat thickness (BT) were not affected by the treatments $(P>0.05)$. However, there was a linear decrease in the final weight (FW), HCW, CCW and weight loss in cooling (WLC), and there was a linear increase in the cold meat yield (CMY) $(P<0.05)$ (Table 4).

For every $1 \%$ of feed restriction, HCW, and CCW decreased by $0.19 \%$ and $0.17 \%$, respectively. However, CMY increased by $0.14 \%$. The decrease of the absolute weight of the hot and cold carcasses is related to the weight decrease in the animals submitted to feed restriction, since CY was not changed. Studies have shown that $\mathrm{CY}$ is affected only when the animals are submitted to severe feed restriction (over $45 \%)$. Under these conditions, there is a decrease in the weight of the organs, owing to the loss of visceral fat and water, leading to an increase in CY (Lovatto et al., 2006).

The amount of meat in the carcass was not influenced. However, the CMY in the carcass increased linearly with the increasing levels of restriction and silage intake, resulting in a leaner carcass. Studies with genetically improved breeds have shown that pigs submitted to feed restriction, in comparison with those fed ad libitum, in both the growing and finishing phases, have a reduced growth rate, resulting in leaner carcasses, because during feed restriction the highest fraction of retained energy is in the form of protein instead of lipids (Daza et al., 2003, Lovatto et al., 2006, Pugliese et al., 2013).

The percentage of weight loss in cooling was unexpected, since the treatment had no effect on the initial and final $\mathrm{pH}$ of the carcass $(0 \mathrm{~h}$ and $24 \mathrm{~h}$ ) and on the subcutaneous fat thickness. The $\mathrm{pH}$ values are related directly to meat quality. The $\mathrm{pH}$ values presented in this study are within the range for normal meat. According to the National Pork Producers Council (1998), pork has quality when it presents an initial pH higher than 5.8 and a final $\mathrm{pH}$ lower than 5.9.

The lower weight loss in the cooling of the carcasses of the animals that received food restriction may be related to the weight of the carcasses. Heavier carcasses present a higher proportion of water in their composition, resulting quantitatively in greater loss (Lebret et al., 2001). In addition to the higher proportion of water, studies by Huff-Lonergan et al. (1998) demonstrated that heavier carcases present greater amounts of energy reserve in the muscles, resulting in a longer time to establish rigor mortis and, consequently, greater loss in cooling.

Therefore, heavier carcasses, with greater glycogen stores, take a longer time for the muscle fibres to relax, and there may be more loss in cooling. Although the muscle glycogen concentration was not evaluated, the amount of hepatic glycogen showed a linear decrease with feed restriction $(P<0.05)$. The authors also observed an increase in the plasma creatinine concentration in the animals submitted to feed restriction (Table 5). This indicates low energy stores in these animals, and consequently rigor mortis was established earlier. 
Table 4 Effect of feed restriction levels with forage cactus silage (FCS) on final weight, carcass yield, hot carcass weight, cold carcass weight, weight loss in cooling, carcass length, cut yield, backfat thickness, cold meat yield, and the amount of meat in the carcass

\begin{tabular}{|c|c|c|c|c|c|c|c|}
\hline \multirow{2}{*}{ Variables } & \multicolumn{4}{|c|}{ Levels of FCS (\%) } & \multicolumn{2}{|c|}{$P$} & \multirow[b]{2}{*}{$C V^{3} \%$} \\
\hline & 0 & 10 & 20 & 30 & Lin. $^{1}$ & Qua. $^{2}$ & \\
\hline FW (kg) & 116.68 & 109.60 & 108.68 & 104.62 & 0.001 & 0.468 & 4.0 \\
\hline CY (\%) & 81.53 & 81.60 & 80.79 & 79.87 & 0.331 & 0.705 & 3.52 \\
\hline HCW (kg) & 47.90 & 44.18 & 43.62 & 41.60 & 0.001 & 0.378 & 4.69 \\
\hline CCW (kg) & 45.56 & 42.98 & 41.72 & 40.66 & 0.001 & 0.317 & 3.81 \\
\hline WLC (\%) & 5.59 & 2.73 & 3.56 & 2.36 & 0.006 & 0.060 & 3.81 \\
\hline $\mathrm{CL}(\mathrm{cm})$ & 97.60 & 97.20 & 98.80 & 96.40 & 0.781 & 0.537 & 3.61 \\
\hline Leg yield & 26.36 & 26.97 & 27.97 & 26.97 & 0.060 & 0.733 & 3.58 \\
\hline Rib yield & 17.75 & 16.42 & 17.35 & 17.15 & 0.063 & 0.573 & 7.05 \\
\hline Shoulder yield & 19.45 & 19.61 & 20.49 & 19.61 & 0.097 & 0.782 & 7.00 \\
\hline Belly yield & 7.95 & 7.03 & 6.93 & 7.13 & 0.065 & 0.191 & 13.77 \\
\hline Neck yield & 4.29 & 4.12 & 4.31 & 3.98 & 0.157 & 0.910 & 17.00 \\
\hline Loin yield $^{\mathrm{a}}$ & 7.13 & 7.67 & 7.71 & 7.66 & 0.502 & 0.559 & 8.11 \\
\hline Fillet yield & 1.71 & 1.57 & 1.78 & 1.60 & 0.060 & 0.836 & 6.90 \\
\hline BT (mm) & 2.84 & 2.34 & 2.34 & 1.91 & 0.100 & 0.650 & 28.10 \\
\hline $\mathrm{pHO}^{\mathrm{b}}$ & 6.02 & 5.95 & 6.10 & 6.03 & 0.468 & 0.066 & 2.09 \\
\hline $\mathrm{pH} 24^{\mathrm{c}}$ & 5.83 & 5.74 & 5.82 & 5.85 & 0.065 & 0.526 & 4.97 \\
\hline CMY (\%) & 57.29 & 58.94 & 60.45 & 61.33 & 0.002 & 0.733 & 3.01 \\
\hline $\mathrm{AMC}(\mathrm{kg})$ & 26.86 & 26.03 & 26.79 & 26.43 & 0.816 & 0.663 & 4.37 \\
\hline
\end{tabular}

a: loin boneless, b: initial $\mathrm{pH}$ (0 hours), c: final $\mathrm{pH}$ (24 hours),

${ }^{1}$ Lin. :linear effect,

${ }^{2}$ Qua.: quadratic effect $(P<0.05)$,

${ }^{3} \mathrm{CV}$ : coefficient of variation,

FW: final weight, CY: carcass yield, HCW: hot carcass weight, CCW: cold carcass weight, WLC: weight loss in cooling, $\mathrm{CL}$ : carcass length, CutY: cut yield, BT: backfat thickness, CMY: cold meat yield, AMC: amount of meat in the carcass, Equations: PF: $\hat{Y}=115.46-0.371 x, r 2=0.91, H C W: \hat{Y}=47.244-0.1946 x, r^{2}=0.91, C C W: \hat{Y}=45.124-0.1596 x, r^{2}=0.95$, WLC: $\hat{Y}=5.5205800811-0.730815675 x, r^{2}=0.73, C M Y: \hat{Y}=57.458+0.1363 x, r^{2}=0.98$

Table 5 Effect of feed restriction associated with forage cactus silage (FCS) on creatinine concentration before and after fasting

\begin{tabular}{|c|c|c|c|c|c|c|c|}
\hline \multirow{2}{*}{$\begin{array}{l}\text { Variables } \\
\text { mg/dL }\end{array}$} & \multicolumn{4}{|c|}{ Inclusion levels of FCS\% } & \multicolumn{2}{|c|}{$P$} & \multirow[b]{2}{*}{$\mathrm{CV}^{3} \%$} \\
\hline & 0 & 10 & 20 & 30 & Lin. $^{1}$ & Qua. $^{2}$ & \\
\hline Creatinine $^{\mathrm{a}}$ & 1.82 & 1.93 & 2.10 & 2.14 & 0.001 & 0.514 & 6.48 \\
\hline Creatinine $^{b}$ & 2.09 & 2.13 & 2.25 & 2.30 & 0.060 & 0.962 & 8.29 \\
\hline
\end{tabular}

${ }^{a}$ Before fasting, ${ }^{\text {b }}$ After fasting

${ }^{1}$ Lin.: linear effect, ${ }^{2}$ Qua.: quadratic effect $(P<0.05),{ }^{3} \mathrm{CV}$ : coefficient of variation

Equation: $\hat{Y}=1.828+0.0113 x, r^{2}=0.95$

The restriction levels associated with silage intake did not influence the absolute weight of the stomach, small intestine, colon, cecum, pancreas, heart, spleen and small intestine length $(P<0.05)$. However, they reduced the absolute weight of the liver and kidneys $(P<0.05)$ linearly (Table 6). The decrease in the liver absolute weight corroborates the decrease in hepatic glycogen (Table 7), as the feed restriction increases. Thus, the decrease in nutrient availability, owing to the feed restriction, causes a 
decrease in hepatic energy reserves (glycogen), especially with the restriction levels of $20 \%$ and $30 \%$, making the liver lighter. However, the relative weight of all organs was not affected by the restriction levels and silage supply $(P>0.05)$ (data not shown), showing that the increase in the absolute weight of the liver and kidneys may also have been changed because of the bodyweight of the animals.

Table 6 Effect of feed restriction associated with forage cactus silage (FCS) on weight of full and empty stomach, small intestine, colon, caecum, liver, heart, kidney, pancreas, spleen and small intestine length

\begin{tabular}{|c|c|c|c|c|c|c|c|}
\hline \multirow{2}{*}{ Variables (kg) } & \multicolumn{4}{|c|}{ Levels of restriction + FCS } & \multicolumn{2}{|c|}{$P$} & \multirow[b]{2}{*}{$\mathrm{CV}^{3} \%$} \\
\hline & 0 & 10 & 20 & 30 & Lin. $^{1}$ & Qua. $^{2}$ & \\
\hline Stomach & 849 & 959 & 808 & 914 & 0.910 & 0.982 & 21.61 \\
\hline Small intestine (SI) & 2347 & 2408 & 2388 & 2223 & 0.551 & 0.445 & 13.66 \\
\hline Full colon & 1787 & 1988 & 2082 & 1738 & 0.957 & 0.237 & 26.77 \\
\hline Full caecum & 437 & 586 & 430 & 420 & 0.579 & 0.346 & 38.65 \\
\hline Liver & 1594 & 1433 & 1399 & 1315 & 0.003 & 0.520 & 9.06 \\
\hline Pancreas & 479 & 412 & 399 & 419 & 0.157 & 0.154 & 14.94 \\
\hline Heart & 419 & 363 & 371 & 392 & 0.437 & 0.082 & 11.76 \\
\hline Kidneys & 317 & 318 & 303 & 269 & 0.003 & 0.096 & 7.18 \\
\hline Spleen & 165 & 172 & 168 & 148 & 0.357 & 0.314 & 17.60 \\
\hline SI length & 18.52 & 18.44 & 18.05 & 18.29 & 0.624 & 0.746 & 6.00 \\
\hline
\end{tabular}

${ }^{1}$ Lin.: linear effect

${ }^{2}$ Qua.: quadratic effect $(P<0.05)$

${ }^{3} \mathrm{CV}$ : coefficient of variation

Equations: liver: $\hat{Y}=1565.9-8.71 x, r^{2}=0.93$, kidney: $\hat{Y}=325.6-1.59 x, r^{2}=0.80$

The concentrations of acetic, propionic and butyric acids in the caecal content and the $\mathrm{pH}$ value $(P>0.05)$ were not affected by the treatments (data not shown). Because of the silage intake, changes were expected in the concentrations of short-chain fatty acids, following the same ratio of acids contained in the silage. Corroborating Varel \& Yen (1997), it is possible there was an adaptation of the bacterial population to the diet with high fibre, which, according to these authors, occurs within 14 days.

When evaluating the biochemical parameters of the blood plasma, the authors verified that before fasting, the restriction levels with forage cactus silage did not affect $(P>0.05)$ the plasma concentrations of total proteins, glucose, triglycerides, cholesterol and albumin (data not shown). However, the creatinine concentration increased linearly $(P<0.05)$ with the restriction of the balanced feed (Table 6). After fasting, no biochemical parameter was influenced $(P>0.05)$. However, the creatinine values increased for all treatments, which may indicate greater muscle catabolism.

In this study, the concentration of creatinine before and after fasting was within the normal range for pigs (1.0-2.7 mg/dL) (Kaneko, 1997). However, the concentration before fasting was below normality in the animals fed ad libitum in comparison with the animals submitted to feed restriction. After fasting, this concentration also increased. These results indicate that animals fed restricted diet were in muscle catabolism, even when consuming the forage cactus silage.

The thickness of the intestinal mucosa of the animals submitted to feed restriction and silage intake decreased as feed restriction levels increased (Table 7). All treatments with feed restriction resulted in lower mucosa thickness in comparison with the control treatment (Figure 1). Because the feed was restricted, there were morphological changes in the intestine, with a decrease in mucosa thickness, which were accentuated with the increasing levels of restriction. In addition, there was a decrease in the amount of the intestinal folds, including no folds for the highest restriction level. These morphological changes cause a decrease between the surface of the intestinal mucosa and the feed, reducing feed absorption (Gomide-Junior et al., 2004). 
Table 7 Duodenum mucosa thickness and semi-quantitative score modified to positive staining of periodic acid Schiff as liver glycogen storage index of pigs fed restriction levels with forage cactus silage (FCS)

\begin{tabular}{|c|c|c|c|c|}
\hline \multirow{2}{*}{ Variables $(\mathrm{mm})$} & \multicolumn{4}{|c|}{ Levels of restriction + FCS } \\
\hline & $0 \%$ & $10 \%$ & $20 \%$ & $30 \%$ \\
\hline Duodenum thickness & $1736^{\mathrm{a}} \pm 84$ & $1216^{\mathrm{b}} \pm 87$ & $1032^{\mathrm{c}, \mathrm{d}} \pm 69$ & $1064^{d} \pm 247$ \\
\hline Liver glycogen index & $2.21^{\mathrm{a}} \pm 0.41$ & $2.07^{\mathrm{a}} \pm 0.26$ & $1.41^{b} \pm 0.50$ & $1.07^{b} \pm 0.20$ \\
\hline
\end{tabular}

${ }^{a, b}$ Means followed by different superscripts in a row differ statistically at $5 \%$ significance by Tukey test $(P<0.05)$

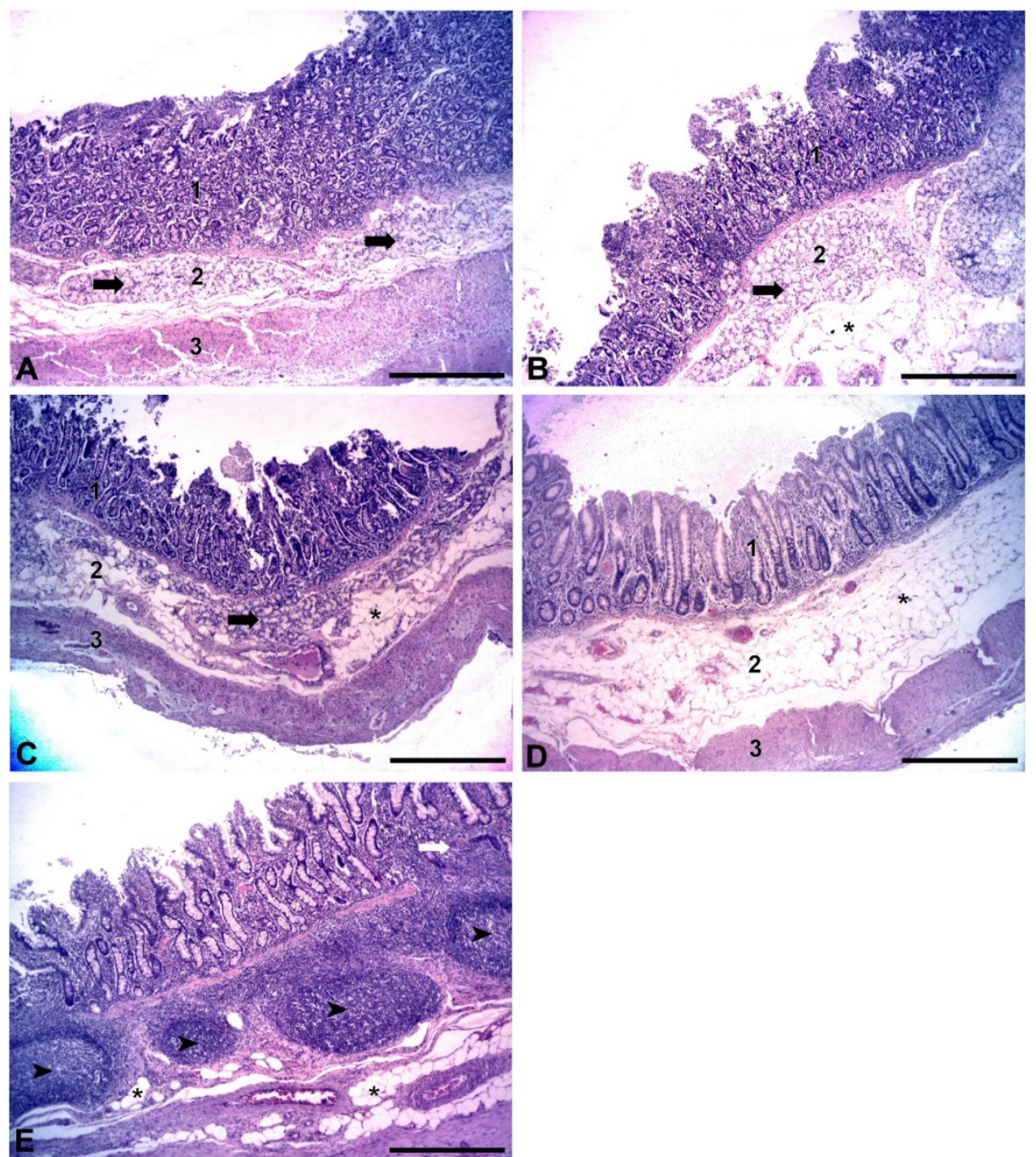

(A: control, B: 10\% feed restriction, C: $20 \%$, D: 30\%, and E: representative of 20 and 30\%).

A) Thick mucosa with mixed glands in the submucosa and muscular layer. B) Mucosa with a lower thickness, with fatty infiltration in the submucosa. However, the glands are still in this layer. C) Mucosa with a lower thickness, a lower amount of glands in the submucosa, and an increase of adipose tissue in the submucosa. D) Mucosa with a lower thickness, absence of glands and a large amount of adipose tissue in the submucosa. E) Submucosa without mixed glands, with large areas of inflammatory processes (arrowheads), including infiltration in the lamina propria of the mucosa (white arrow). It is also observed a large amount of fatty tissue in the submucosa. Mucosa (1), submucosa (2), muscle (3), submucosal glands (arrows), adipose tissue (asterisk). Haematoxylin-eosin staining. Bar: 1000 $\mu \mathrm{m}$.

Figure 1 Photomicrographs of duodenum of pigs fed various levels of feed restriction and forage cactus silage supply 
The increase in feed restriction also led to a decrease in the amount of glands (Brunner's glands) in the submucosal layer, and the disappearance of these glands in many intestinal regions of the animals that were submitted to higher restriction levels (20\% and 30\%) (Figure 1). Probably the decrease in the number of such glands may be associated with the decrease in intake volume, since these glands produce secretions (mucus) that assist the feed bolus transit (Junqueira \& Carneiro, 2013). In $42.1 \%$ of the analysed photomicrographs of the animals submitted to restriction of $20 \%$, and in $70.6 \%$ of the analysed photomicrographs of the animals fed $30 \%$ restriction, there were no glands in the submucosa. In these regions, these glands were observed to be replaced with adipose tissue. There were fewer goblet cells in the intestinal epithelium of the animals submitted to feed restriction of $30 \%$. The decrease in the number of glands, whether from the intestinal epithelium or submucosa, may affect animal health since they are important for the regular flow of the feed bolus through the intestine, preventing constipation and protecting the intestinal mucosa from injuries caused by pathogen agents (Gomide-Junior et al., 2004). The authors also found areas with inflammatory processes in the submucosa and, in some cases, in the lamina propria of the mucosa. This finding may also be because of lower production of mucus, since protection against bacterial infection requires an intact mucus layer, given that protection efficiency depends on the amount and quality of mucus (Fortun-Lamothe \& Boullier, 2007). These findings were more frequently observed in the $20 \%$ and $30 \%$ restriction levels (Figure 1 ).

The decrease in the amount of energy and nutrients available to the animals negatively influenced the development of the small intestine, reducing its mucosa thickness and consequently the surface absorption of nutrients. Pluske et al. (1997) demonstrated that villus height and mucosa are positively correlated with the bodyweight gain and nutrient intake. Similarly, Dong \& Pluske (2007) reported that intestinal development is directly related to feed intake. Animals fed a restricted diet have a lower development of the intestine. Therefore, they have lower feed utilization. This occurs because the gastrointestinal tract has high demand for energy and nutrients, which are required for cell proliferation (Lovatto et al., 2006). Although the mucus was not measured directly, the decrease in the number of goblet cells and Brunner's glands indicates less mucus production with the decrease of feed intake.

Lower availability of nutrients may also reduce the body's defence capacity, as they play an important role in immunity development, acting as substrates for enzymes, cell proliferation during the immune response, and effective synthesis of molecules (antibodies, nitric oxide, lysozyme) and cytokines (FortunLamonthe \& Boullier, 2007).

With regard to deposition of fatty tissue in the intestinal submucosa of the animals fed higher restriction levels, there is no information about this process in the literature. However, the space that originated from the former gland may have been filled by adipose tissue, as occurs in the dermis of certain fish (Guerra et al., 2006).

There was no significant effect $(P>0.05)$ of the feed restriction levels associated with the supply of forage cactus silage on the cost of feed per kilogram of live weight, economic efficiency index and cost index of finishing pigs (Table 8).

Table 8 Initial weight, final weight, cost of feed, cost of silage, cost of feed per kilogram of live weight gain, economic efficiency index and cost index of pigs fed diets containing various levels of feed restriction with forage cactus silage (FCS)

\begin{tabular}{|c|c|c|c|c|c|c|c|}
\hline \multirow{2}{*}{ Variables } & \multicolumn{4}{|c|}{ Levels of restriction + FCS } & \multicolumn{2}{|c|}{ Effect1 } & \multirow{2}{*}{ CV2 \% } \\
\hline & $0 \%$ & $10 \%$ & $20 \%$ & $30 \%$ & Regression & Dunnett & \\
\hline Initial weight (kg) & 64.34 & 63.78 & 64.04 & 63.94 & - & - & - \\
\hline Final weight $(\mathrm{kg})$ & 116.68 & 109.6 & 108.68 & 104.62 & - & - & - \\
\hline $\mathrm{CS}, \mathrm{R} \$ \mathrm{~kg}$ & 00 & 0.27 & 0.27 & 0.27 & - & - & - \\
\hline $\mathrm{CF} 1, \mathrm{R} \$ / \mathrm{kg}$ & 0.97 & 0.97 & 0.97 & 0.97 & - & - & - \\
\hline $\mathrm{CF} 2, \mathrm{R} \$ / \mathrm{kg} / \mathrm{LWG}$ & 2.28 & 2.34 & 2.24 & 2.21 & NS & NS & 7.78 \\
\hline EEI (\%) & 95.28 & 90.70 & 96.87 & 100 & NS & NS & 7.20 \\
\hline $\mathrm{Cl}(\%)$ & 105.33 & 110.79 & 103.44 & 100 & NS & NS & 7.76 \\
\hline
\end{tabular}

NS: non-significant effect at $5 \%$ probability by Tukey test $(P>0.05)$

${ }^{1}$ Regression: regression analysis, Dunnett's test; ${ }^{2} \mathrm{CV}$ : Coefficient of variation

CF1: cost of feed, CS: cost of silage, CF2: cost of feed per kilogram of live weight gain, EEl: economic efficiency index, Cl: cost index 
These results demonstrate that producers may produce lighter animals and carcasses with a higher proportion of meat and less fat, without economic losses.

\section{Conclusions}

For finishing pigs, forage cactus silage has a sufficient concentration of metabolizable energy. However, it has low acceptance by the animals. In terms of feed conversion, the yield of carcass, cuts and the intestinal health, the balanced feed may be quantitatively restricted up to $10 \%$ of the daily intake.

\section{Acknowledgements}

Financial support from the Conselho Nacional de Pesquisa of Brazil (CNPQ), project number 562840/2010-9, is acknowledged.

\section{Authors' Contributions}

GMA was responsible for the project execution and text correction, TDDM was responsible for the design of the project and for the execution, PENG was responsible for the zootechnical analyzes and text correction, LAFP was responsible for the design of the project, RSO was responsible for the zootechnical analyzes, ACO was responsible for the zootechnical analyzes, JHVS was responsible for the design of the project, RRG was responsible for the histomorphological analyses and text correction.

\section{Conflict of Interest Declaration}

I Gilson Mendes Araújo declare that this article entitled "Productive aspects of pigs fed forage cactus silage associated with feed restriction" submitted with the co-authors T.D.D. Martins, P.E.N. Givisiez, L.A.F. Pascoal, R.S. Oliveira, A.C. Oliveira, J.H.V. Silva \& R.R. Guerra to the The South African Journal of Animal Science (SAJAS) does not have any kind of conflict of interests.

\section{References}

ABCS (Associação Brasileira de Criadores de Suínos), 1973. Método Brasileiro de Classificação de Carcaças. Estrela, Brasília, Brazil.

Bellaver, C., Fialho, E.T., Protas, J.F.S. \& Gomes, P.C., 1985. Radícula de malte na alimentação de suínos em crescimento e terminação. Pesqui. Agropecu. Bras. 20, 969-74.

Bridi, A.M. \& Silva, C.A., 2007. Métodos de avaliação da carcaça e da carne suína. Midiograf, Londrina, Brazil.

Covasa, M. \& Ritter, R.C., 2000. Adaptation to high-fat diet reduces inhibition of gastric emptying by CCK and intestinal oleate. Am. J. Physiol. 278, 166-170.

Çürek, M. \& Özen, N., 2004. Feed value of cactus and cactus silage. Turk. J. Vet. Anim. Sci. 28, 633-639.

Daza, A., Rodriguez, I., Ovejedo, I. \& López-Bote, C.J., 2003. Effect on pig performance of feed restriction during the growth period. Span. J. Agric. Res. 1, 3-8.

Dong, G.Z. \& Pluske, J.R., 2007. The low feed intake in newly weaned pigs: problems and possible solutions. AsianAustralas. J. Anim. Sci. 20, 440-452.

FAO, 2013. Agro-industrial utilization of cactus pear. Rome, Italy.

Fortun-Lamothe, L. \& Boullier, S., 2007. A review on the interactions between gut microflora and digestive mucosal immunity. Possible ways to improve the health of rabbits. Livest. Sci. 107, 1-18.

Gomes, M.F.M., Barbosa, H.P., Fialho, E.T., Ferreira, A.S. \& Lima, G.J.M.M., 1991. Análise econômica da utilização de triguilho para suínos. EMBRAPA-CNPSA, Concórdia, Brazil.

Gomide-Junior, M.L., Sterzo, E.V., Macari, M., \& Boleli, I.C., 2004. Use of scanning electron microscopy for the evaluation of intestinal epithelium integrity. Rev. Bras. Zoot. 33, 1500-1505.

Guerra, R.R., Santos, N.P., Cecarelli, P., Mangetti, A.J., Silva, J.R.M.C. \& Hernandez-Blazquez, F.J., 2006. Stratum adiposum, a special structure of the African catfish skin (Clarias gariepinus, Burchell 1822). Anat. Hist. Embriol. 35, 144-146.

Guidoni, A.L., 2000. Melhoria de processos para a tipificação e valorização de carcaças suínas no Brasil. In: Conferência internacional virtual sobre a qualidade de carne suína, EMBRAPA-CNSA, Concórdia. pp. 221- 234 (in Portuguese).

Heleno, R.A., Santos, L.M., Miglino, M.A., Peres, J.A. \& Guerra, R.R., 2011. Biometria, histologia e morfometria do sistema digestório do cachorro-do-mato (Cerdocyon thous) de vida livre. Biotemas 24, 111-119.

Huff-Lonergan, E., Kuhlers, D.L., Lonergan, S.M. \& Jungst, S.B., 1998. Characterization of pork quality in response to five generations of selection for lean growth efficiency. J. Anim. Sci. 76, 151-162.

Instituto Adolfo Lutz, 1985. Normas Analíticas do Instituto Adolfo Lutz (3th ed.). IMESP, São Paulo, Brazil.

Ishak, K., Baptista, A., Bianchi, L., Callea, F., Groote, J.D., Gudat, F., Denk, H., Desmet, V., Korb, G., Macsween, R.N.M., Phillips, M.J., Portmann, B.G., Poulsen, H., Scheuer, P.J., Schmid, M. \& Thaler, H., 1995. Histological grading and staging of chronic hepatitis. J. Hepatol. 22, 696-699.

Junqueira, L.C. \& Carneiro, L., 2013. Histologia básica. 12th edition. Guanabara Koogan, Rio de Janeiro, Brazil.

Kaneko, J., 1997. Serum proteins and the dysproteinemias. In: Clinical Biochemistry of Domestic Animals. 5th edition. Academic Press, San Diego, USA.

Le Gall, M., Quillien, L., Sève, B., Guéguen, J. \& Lallés, J.P., 2007. Weaned piglets display low gastrointestinal digestion of pea (Pisum sativum L.) lectin and pea albumin. J. Anim. Sci. 2972-2981. 
Lebret, B., Juin, H., Noblet, J. \& Bonneau, M., 2001. The effects of two methods of increasing age at slaughter on carcass and muscle traits and meat sensory quality in pigs. Anim. Sci. 72, 87-94.

Lohmann, A.C., Pozza, P.C., Nunes, R.V., Pozza, M.S.S., Venturi, I. \& Pasquetti, T.J., 2010. Digestibilidade da silagem de grãos úmidos de milho com diferentes granulometrias para suínos. Arq. Bras. Med. Vet. Zootec. 62, 154-162.

Lovatto, P.A., Sauvant, D., Noblet, J., Dubois, S. \& Van Milgen, J., 2006. Effects of feed restriction and subsequent refeeding on energy utilization in growing pigs. J. Anim. Sci. 84, 3329-3336.

Matterson, L.D., Potter, L.M. \& Stutz, M.W., 1965. The metabolizable energy of feed ingredients for chickens. Agric. Exp. Stat. Res. Rep., 7, 3-11.

McDonald, P., Henderson, A.R. \& Heron, S.J.E., 1991. The Biochemistry of Silage. 2nd edition. Chalcombe, New York, USA.

National Pork Producers Council (NPPC), 1999. Pork quality targets. <http://www.nppc.org/facts/targets.html>

Pekas, J.C., 1968. Versatile swine laboratory apparatus for physiologic and metabolic studies. J. Anim. Sci. 27, 1303-1306.

Pugliese, C., Sirtori, F. \& Franci, O., 2013. Feeding strategies for local breeds in view of product quality. Acta Agric. Slov. 4, 69-75.

Pluske, J.R., Hampson, D.J. \& Williams, I.H., 1997. Factors influencing the structure and function of the small intestine in the weaned pig: a review. Livest. Prod. Sci. 51, 215-236.

Rosa, A.F., Sobral, P.J.A. \& Gomes, J.D.F., 2001.Determinação das características físico-químicas da carne de suínos em fase de crescimento.Revista TeCCarnes, 3, 13-18.

Rostagno, H.S., Albino, L.F.T., Donzele, J.L., Gomes, P.C., Oliveira, R.S., Lopes, D.C., Ferreira, A.S. \& Barreto, S.L.T., 2011. Tabelas brasileiras para aves e suínos: composição de alimentos e exigências nutricionais. 3rd edition. Editora UFV, Viçosa, Brazil.

Sakomura, N.K. \& Rostagno, H.S., 2007. Métodos de pesquisa em nutrição de monogástricos. First edition. Funep, Jaboticabal, Brazil.

Santos, M.V.F., Castro, G.A.G., Perea, J.M., García, A., Guim, A. \& Pérez Hernández, M., 2010. Fatores que afetam o valor nutritivo das silagens de forrageiras tropicais. Arch. Zootec. 59, 25-43.

Sheperd, A.C., Maslanka, M., Quinn, D. \& Kung Jr, L., 1995. Additives containing bacteria and enzymes for alfalfa. J. Dairy Sci., 78, 565-572.

Silva, D.J. \& Queiroz, A.C., 2002. Análise de alimentos. Métodos químicos e biológicos (3th ed.). Editora UFV, Viçosa, Brazil.

Sibbald, I.R. \& Slinger, S.J., 1963. A biological assay for metabolizable energy in poultry feed ingredients together with findings which demonstrate some of the problems associated with the evaluation of fats. Poult. Sci. 42, $313-325$

Van Soest, P.J., Robertson, J.B. \& Lewis, B.A., 1991. Methods for dietary fiber, neutral detergent fiber, and nonstarch polysaccharides in relation to animal nutrition. J. Dairy Sci. 74, 3583-3597.

Varel, V.H. \& Yen, J.T., 1997. Microbial perspective on fiber utilization by swine. J. Anim. Sci. 75, 2715-2722. 